\title{
Tajik Chinese
}

National Cancer Institute

\section{Source}

National Cancer Institute. Tajik Chinese. NCI Thesaurus. Code C158195.

A Chinese person from the Tajik ethnic group. 